\title{
THE EFFECT OF LIGHT SOURCE AND HEAT ON EGGS PRODUCTION IN POULTRY FARMS
}

\author{
Hanafy W.M. *
}

\section{ABSTRACT}

The present study was conducted to identify the average quantity of eggs production per week using incandescent light bulbs and the compact fluorescent light (CFL) lamps energy-saving light at two departments ( $A$ and $B$ ) of poultry farm each one divided into five sectors under five different temperatures were 20, 21, 22, 23 and $24{ }^{\circ} \mathrm{C}$. Each sector were studied to find the relation between the eggs production of broiler breeders (cobb 500) and the light source in addation to increase of ambient temperature.The individual sector contains 4165 birds and beginning at the age from 24 to 56 week. Experiments were carried out at Misr Ismalia poultry farm Co. for broiler breeders and eggs production at "Abo - Sultan" of Ismalia City during the period from october, 2016 to may, 2017. The Average weekly quantity and the percentage of egg production for each sector in two departments were calculated and compared for 32 weeks. Eggs weight also compared. The obtained data cleared that the average weekly quantity of produced eggs in the shed $A$ for sectores $A_{1}, A_{2}, A_{3}, A_{4}$ and $A_{5}$ were 84466, 83606, 82924, 82656 and 80961 egg, while in the shed $B$ for sectores $B_{1}, B_{2}, B_{3}, B_{4}$ and $B_{5}$ they were 82039, 80923, 79517, 78640 and 77418 eggs at temperature (20, $21,22,23$ and $24{ }^{\circ} \mathrm{C}$ ) respectively using incandescent light bulbs and CFL lamps during the period extenuation to 32 weeks in the poultry farm. The percentage of average weekly produced eggs decreased from $1 \%$ to $4.15 \%$ in the shed A while it decreased from $1.36 \%$ to $5.63 \%$ in the shed $B$ when heat temperature increased from $20{ }^{\circ} \mathrm{C}$ to $24{ }^{\circ} \mathrm{C}$ in different sectors. The percentage of average weekly produced eggs in the shed $A$ increased by $2.87 \%, 3.21 \%, 4.11 \%, 4.86 \%$ and $4.38 \%$ in sectores $A 1, A 2$, A3, A4 and A5 comparing to sectores B1, B2, B3, B4 and B5 in the shed $B$ respectively. The Eggs weight in sheds A ranged from 48.5 to 72.2 while it ranged from 49.7 to 77.8 in the shed $B$ respectively.

Keywords: farm, poultry, light, incandescent bulbs, CFL lamps, heat, egg, closed shed.

*Lecturer, of Ag. Eng. Dept., Faculty Of Agric.and Natural Resources, Aswuan Univ. 


\section{INTRODUCTION}

Doday, incandescent light bulbs are being phased out by more energy efficient alternatives, including (CFL) and light 1 emitting diodes (LED). Siopes (1984) carried out some experiments on large white turkey breeder hens were exposed to incandescent or cool-white $(\mathrm{CW})$ fluorescent light.As a result, total egg production was significantly lower in the $\mathrm{CW}$ fluorescent (67.9 eggs/hen) than the incandescent treatment (75.2 eggs/hen).

St-Pierre et al.(2003) said that the poultry farming is no exception and the effect of stress caused by elevated temperatures can result in heavy economic losses from increased mortality and reduced productivity.

Estrada-Pareja et al.(2007) said that ambient temperature (AT) above 25 is stressful for birds when it is accompanied by high relative humidity Furthermore, it has been demonstrated and thus lead to disturbance in production.

Gerry (2007) reported that either incandescent or fluorescent lights may be used. Commercially, fluorescent lights are a cheaper long-term proposition because of their greater light efficiency and low maintenance and running costs. However, installation costs are higher. These fluorescent will reduce running costs significantly.

Neil (2009) said that incandescent bulbs are inefficient because nearly $90 \%$ of the power used by the bulb is released as heat rather than light this may be an attractive benefit in the winter, and these raise cooling costs in the summer and they have a lifespan of 1,000 hours. The most poultry house replacement it by Compact florescent bulbs (CFL) bulbs which have 10,000 hour lifespan and use $75 \%$ less energy than incandescent. CFLs spread light more evenly throughout the poultry house, which prevents birds from clustering in one area bulbs.

Talukder et al. (2010) determined the productive and performance of flock was evaluated by measuring egg production, feed consumption, egg weight and egg shell thickness. High temperature (above $27^{\circ} \mathrm{C}$ ) affects feed consumption, egg weight and egg shell thickness while relative humidity has less impact on egg production, egg weight and feed consumption. 
Borrile et al.(2013) said that incandescent bulbs are commonly used to provide uniform illumination, however its conversion rate from electrical energy to luminous energy is low, which generates a large amount of heat and provides a low durability, increasing the production costs.

Huber-Eicher et al.(2013) said that the cost of incandescent bulbs is low, but they are thought to increase the production costs in the poultry industry due to their inefficiency, shorter life span and less reliability. LEDs spend less energy, but are more expensive than mini fluorescent lamps.

Mendes et al.(2013) said that fluorescent lamps may be an alternative to incandescent lamps, considering that they produce greater brightness per Watt. However, its luminous intensity decreases with time, which means that luminous flux depreciation occurs. Besides, they have a higher initial cost.

Commercial-industrial (2014) reported that using LED- lighting system at chicken farms can increase egg output and quality and the same "average" farm equipped with LEDs representing a savings of 95\% the energy for the same flock per year use incandescent. Kenyan chicken farms' net income increased by $15 \%$ using both the LED- and fluorescent lighting. Javid (2014) noticed that small egg size group, followed by medium and large egg size groups.

Molino et al. (2015) found that the main advantage of the LED is the energy saving (80\% less energy waste as compared to incandescent bulbs and 50\% compared to fluorescent lamps), longer shelf life and color diversity.

Cobb-vantress (2015) mentioned that right bulbs could lower your electric bill selection. The key selection criteria includes the type of bulb its wattage, lumen output or intensity, cost, lifespan and warranty.

Jacob (2015) said that produce eggs depend on several variables, including light management.

Kamanli et al. (2015) compared egg production of laying hens and energy cost of the production in hen houses illuminated by incandescent bulbs, mini fluorescent lamps or LEDs. Egg production determined throughout 52 weeks of the production period for $16 \mathrm{~h}$ per day. The use of 
incandescent bulb, mini fluorescent lamps and LEDs did not cause a significant difference and numbers of eggs production and it was $200 \pm$ $2.13,198 \pm 2.04$ and $196 \pm 3.00$ respectively.

Tamil (2018) reported that birds reared under increased day-light produce more eggs due to the release of Follicle Stimulating Hormone (FSH) and luteinizing Hormone (LH) from the pituitary. Brightness of light also has influence on egg production. For maximum egg production, 16 hours light is needed during peak egg production period.

This study amied to estimate and compare the average weekly broiler breeders eggs production in the poultry farm at two departments (A and B) using two different light sources and ambient temerature. The quantity of the eggs production was applied to determine the relation between eggs production and the light source in addation to increase of ambient temperatures for 32 weeks beganing age production at 24 week. change light source and ambient temperatures on closed sheds A and B sectors will result in differnent data. The hightest value eggs production will apper and accombiend with the best light source and ambient temerature.

To achieve this aim the following was carried out.

1- Comparing between the average weekly egg production of broiler breeders at five sectors in the sheds A and B.

2- Comparing between the average weekly quantity of broiler breeders egg produce by incandescent light bulbs and CFL lamps at five sectors for sheds A to B.

3- pointing to the best lamps and temperature in different sectors according to increasing of eggs production.

4- Comparing between the average weekly egg weight in sheds A and $\mathrm{B}$.

\section{MATERIALS AND METHODS}

The experiments were carried out in "Misr Ismalia poultry farm" Co. for broiler breeders and eggs production at "Abo-Sultan" of Ismalia City. In this research two source of light were used in addation to change ambient temperature. The strain of broiler breeders was a cobb 500 .

\section{METHDOLOGY:-}

This research was conducted to accounting and compare the average weekly broiler breeders eggs production. broiler breeders farm was 
divided into two departments ( $\mathrm{A}$ and $\mathrm{B}$ ) according to the light sources, the frist was lighted with incandescent light bulbs and the second was lighted by CFL lamps and each depart was also divied into five sectors $\left(A_{1}, A_{2}\right.$, $A_{3}, A_{4}, A_{5}, B_{1}, B_{2}, B_{3}, B_{4}$ and $B_{5}$ ) according to another factor is change of

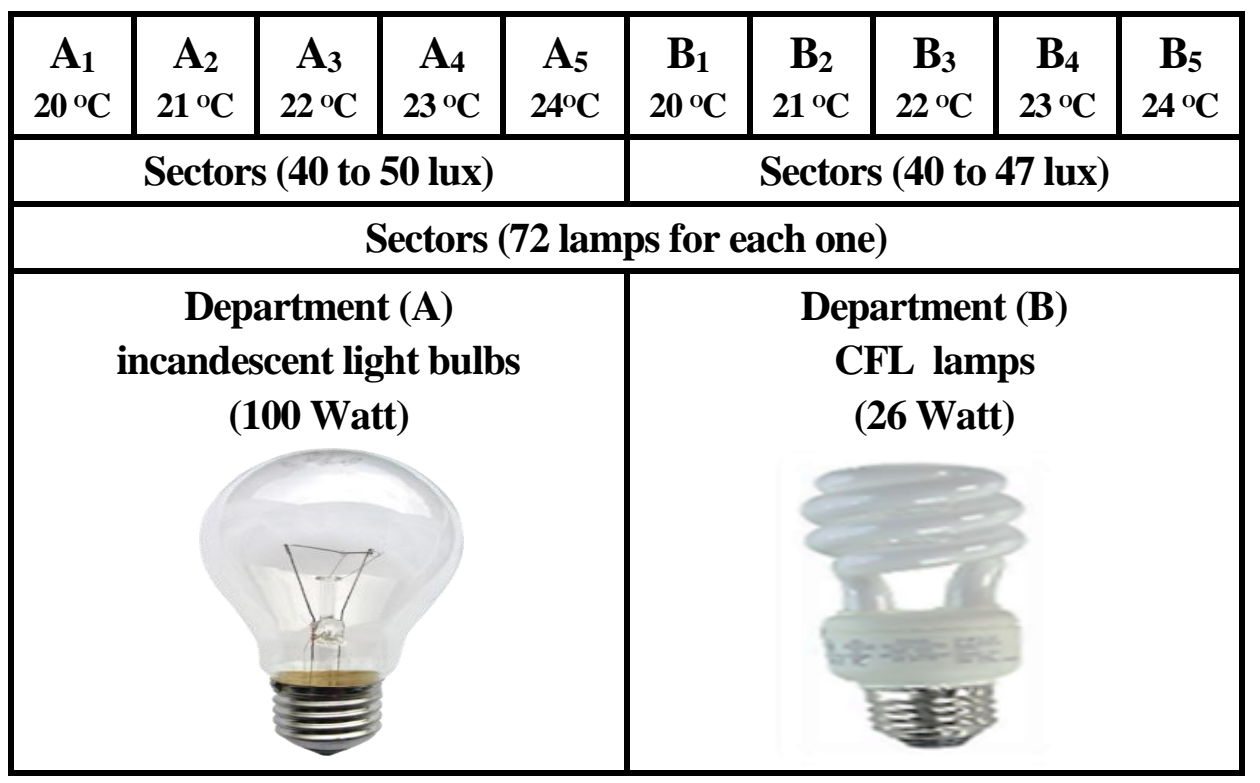

Fig. (1): Illusteration of the Distribution of Sectors at closed sheds $A$ and $B$ in poultry farm.

ambient temperature, five temperatures of $20,21,22,23$ and $24{ }^{\circ} \mathrm{C}$ were applied Fig.(1). The individual sector contains 4165 birds.Sector length was 12 meters while the width was 80 meters. The number of used lamps on each sector was seventy two lambs with capacity of 100 watts in the shed A while it was 26 watts in the shed B. Each bulb covers an area of $13.33 \mathrm{~m}^{2}$ and a typical 100-watt incandescent light bulb produces approximately 1600 lumens. A similar intensity can be achieved with a 23-28 watt CFL lamp Keefe, T. J. (2010) and Wikipedia (2017) Tabel (1). The number of daily lighting 16 hours per day where the lamps were located at a height of 2.5 meters from the level of the bird and the measured intensity of lighting in the area surrounding the lamp ranged from 40 to 50 lux for incandescent light bulbs while it range from 40 to 48 lux for CFL lampes by lux meter in the sheds sectors besides the chikens. Eggs was collected manually 3-4 times daily in winter and 5-6 times in summer. 
Table (1): comparison between the several different types of bulbs and how they compare in each of these criteria.

\begin{tabular}{||c||c|c|c|c||}
\hline Bulb tybe & Watts & \begin{tabular}{|c|c||} 
Life time \\
(hours)
\end{tabular} & $\begin{array}{c}\text { Luminous } \\
\text { efficacy } \\
\text { (lm/W) }\end{array}$ & $\begin{array}{c}\text { Retail } \\
\text { (LE) }\end{array}$ \\
\hline Incandescen & 100 & 1000 & 14.3 & 4 \\
\hline CFL lamp & $23-28$ & 8,000 & 57.14 & 35 \\
\hline LED lamp & $15-22$ & 25,000 & 80 & $120-245$ \\
\hline \hline
\end{tabular}

The study beginning at the age from 25 for broiler breeders and continaued to a period of 32 weeks. This research amied to fined the relation between the average weekly poultry eggs production and the light source in addation to increase ambient temperature. In this experiment five section compared with each others to determine the average ratio of weekly broiler breeders eggs production to arrive to the best light source and ambient temperature in the five sectors of sheds A and B.Five sectors of sheds A and B were also compared.

The collected data about the average weekly broiler breeders eggs proudction were Scheduled in two groups:

1- The frist which including sectors $\left(A_{1}, A_{2}, A_{3}, A_{4}, A_{5}\right)$.

2- The second which including sectors $\left(B_{1}, B_{2}, B_{3}, B_{4}, B_{5}\right)$.

Measured of the average weekely broiler breeders eggs proudction on the five sectors on two departments $\mathrm{A}$ and $\mathrm{B}$, number of spoliage lamps, intensity of lighting These results were analyzed .

\section{Measuring Instruments Data.}

Digital thermometer Model (TPM -10) series hand held Instrument. With a thermocouple was used for monitoring temperature with accuracy of \pm 1 ${ }^{\circ} \mathrm{C}$ and at range $\left(-50{ }^{\circ} \mathrm{C} \sim 110^{\circ} \mathrm{C}\right)$ by reading liquid crystal display (LCD ) and operating in environment Humidity: range 5\% 80\%.

Metal strip meter for measuring the light source height.

Digital LUX-Meter Model (Lixioibs) series hand held Instrument. With a Light sensor with angle, adjusting international, standard caliber of lighting $(\varnothing 22 \mathrm{~mm})$ used for monitoring intensity of lighting by reading liquid crystal display at three ranges were 
Range $_{1}$ 0-1, 999 LUX accuracy ( $\pm 4 \mathrm{rdg}+2 \mathrm{~d}$ )

Range $_{2} 2000-19,999$ LUX accuracy $( \pm 4$ rdg $+2 d)$

Range $_{3}$ 20,000 - 100,000 LUX accuracy ( \pm 5 rdg +2 d)

Digital scalar SF400 with accuracy of $0.1 \mathrm{gm}$ and at range $(1 \mathrm{gm} \sim 10 \mathrm{~kg})$

\section{Poultry eggs proudction Calculations.}

1- The average percentage of proudction eggs per week (qep\%)

$$
\begin{aligned}
& \% \mathrm{qe}_{\mathrm{p}}=\frac{\mathrm{qe}_{\mathrm{p}} / 7}{\mathrm{qe}_{\mathrm{R}}} \times 100 \longrightarrow \text { (1) } \\
& \text { where } \\
& \qquad \mathrm{qe}_{\mathrm{p}}=\text { quantity of eggs produce in the Sector weekly (eggs/w.) } \\
& \mathrm{qe}_{\mathrm{R}}=\text { quantity of poultry in the Sector }
\end{aligned}
$$

2- The percent of decrease or increase eggs proudction in sector to

$$
\begin{gathered}
\text { other } \\
\% \mathrm{qe}_{\mathrm{Ps}}
\end{gathered}=\frac{\mathrm{q}_{\mathrm{ePs} 1}-\mathrm{q}_{\mathrm{ePs} 2}}{\mathrm{q} \mathrm{ePs}_{\mathrm{es}}} \times 100 \stackrel{\left(\mathrm{q} \mathbf{e}_{\mathrm{Ps}} \%\right)}{\longrightarrow}(2)
$$

where

$$
\begin{aligned}
& \mathrm{q}_{\text {ePs} 1}=\text { quantity of the total eggs produce in sector } 1 \\
& \mathrm{q}_{\text {ePs2 }}=\text { quantity of the total eggs produce in sector } 2
\end{aligned}
$$

Costs was calculated according to the following model in sheds (A and B) sectors :-

The average weekly cost of electrical energy (A.W.C.E) :-

A.W.C.E $=$ N.L.S $\times$ N.H.L $\times$ C.O.L $($ K.W $) \times$ N.P.C.D $\times$ P.K.W $/ 7 \rightarrow(3)$

N.L.S $=$ Number of lamps in the sector

N.H.L $=$ Number of hours of lighting

C.O.L $=$ Consumption of one lamps per (K.W)

N.P.C.D $=$ Number of productive cycle days

P.K.W = Price of K.W (L.E)

\section{Costs of buying bulbs in Poultry farm :-}

Price of lamps $=$ N.L.P.C $\times$ P. b $/ 7 \longrightarrow$ (4)

\section{Costs of maintenance bulbs in Poultry farm:-}

Price of spoliage incandescent bulbs $=$ N.S.B.W $\times$ N.P.C.W $\times$ P. b $/ 7 \rightarrow(5)$ 
N.S.B = number of spoliage bulbs weekly

N.P.C.W $=$ Number of productive cycle weekly

P. $b=$ Price of bulb (L.E)

The total cost to produce one egg in sheds (Aand B) different sectors.

Total costs $=($ cost of electricity + cost of lamps + cost of maintenance $)(6)$ The production cost per one egg (P.C.E):-

P.C.E $=$\begin{tabular}{|cc} 
Total cost \\
\hline A.W.P.E.S
\end{tabular}$\times 100$ P. (piaster) $\longrightarrow$ (7)

A.W.P.E.S = Average weekly produce eggs in sector

\section{RESULTS AND DISSCUATIO}

The experimented was investigated using two light sources incandescent light bulbs and CFL lamps in the sheds A and B at five sectors in poultry farm under five ambient temperatures were $20,21,22,23$ and $24{ }^{\circ} \mathrm{C}$ and the results was discussed as follows :-

\section{Eggs production:-}

Figs.(2) and (3) showed the average weekly amount of eggs in closed shed A divided to five sectors $A_{1}, A_{2}, A_{3}, A_{4}$ and $A_{5}$ lighted with incandescent light bulbs and closed shed $\mathrm{B}$ with sectors $\mathrm{B}_{1}, \mathrm{~B}_{2}, \mathrm{~B}_{3}, \mathrm{~B}_{4}$ and $\mathrm{B}_{5}$ lighted with $\mathrm{CFL}$ lamps. Five different temperature of 20, 21, 22, 23 and $24{ }^{\circ} \mathrm{C}$ were applied in both sectors during the period extension of 32 weeks. It noticed that the eggs productivity in shed A was higher than shed B for all sectors and the highest value of production eggs of 84466 was accompanied with a sector $A_{1}$ at temperature of $20{ }^{\circ} \mathrm{C}$ while the lowest one of 77418 with sector $\mathrm{B}_{5}$ at temperature of $24{ }^{\circ} \mathrm{C}$ compared to other sectors and temperature. All CFL bulbs lose light intensity over time and these explain decrease eggs production comparing to incandescent light bulbs. However, excessive dust and dirt accumulation can potentially reduce luminosity from $10-20 \%$ minimize this by cleaning bulbs and these may be increase egg production. It noticed also that the increase of temperature from 20 to $24{ }^{\circ} \mathrm{C}$ caused a reduction in the weekly mount of eggs by percentages from $1 \%$ to $4.15 \%$ for shed A and from $1.36 \%$ to $4.14 \%$ for shed B in the mentioned sectors. Data can be referred to higher temperature reduce egg production because it reduce the productive 
performance of birds and the high temperatures can often be accompanied by high relative humidity $(\mathrm{RH})$, as this unleash various pathophysiological response in birds . Furthermore, it has been demonstrated that this response induces heat stress in chickens, and thus lead to disturbance in production in addition to feed consumption was lower at the higher temperature. All studies indicate that high temperatures reduce the efficiency of utilizing feed energy for productive purposes. Birds not only eat less at high temperature, but also produce less per unit of intake.

Fig. (4) pointing to the average weekly amount of eggs production in the five sectors of shed A comparing to the sectors of shed B. It noticed that the percent of total produce eggs in the shed A increased by $2.87 \%, 3.21 \%, 4.11 \%, 4.86 \%$ and $4.38 \%$ in sectors $\mathrm{A} 1, \mathrm{~A} 2, \mathrm{~A} 3, \mathrm{~A} 4$ and $\mathrm{A} 5$ comparing to sectors B1, $\mathrm{B} 2, \mathrm{~B} 3, \mathrm{~B} 4$ and $\mathrm{B} 5$ in the shed $\mathrm{B}$ respectively.

The (T- TEST) statistical analysis in pairs indicates that the calculated $t$ (11.061) is larger than that of the $t_{0.05}= \pm$ (2.78) and $t_{0.01}= \pm$ (4.6) tabular and this means that the experiment was high significant.(Kwanchi and Arturo 1984).

Fig.(5) shows an Average weekly eggs weight values curve for a broiler breeders in the two sheds (A and B) at the poultry farm. The weight of the eggs increases to the peak quickly and then increases slowly. It noticed that egg weight dived into three size categories small (48.5-61.2 g), medium (61.4-67 g) and large (67.2-77.8 g) during the study period and egg weight in shed B was higher than shed A this may be due to small eggs lost the highest percentage of moisture than large eggs especially in incandescent light bulbs comparing to CFL lamps which released heat rather than others bulbs. Egg size increases in shed B comparing to shed A so it be attractive for customers.

\section{The cost:-}

The cost in sheds (A and B) sectors calculated as fllowes:-

\section{1-The average weekly cost of electrical energy}

\section{Shed (A)}

$$
\text { A.W.C.E }=72 \times 16 \times 0.1 \times 224 \times 1.5 / 7=5.530 \text { L.E }
$$

\section{Shed (B)}

$$
\text { A.W.C.E }=72 \times 16 \times 0.026 \times 224 \times 1.5 / 7=1.438 \text { L.E }
$$




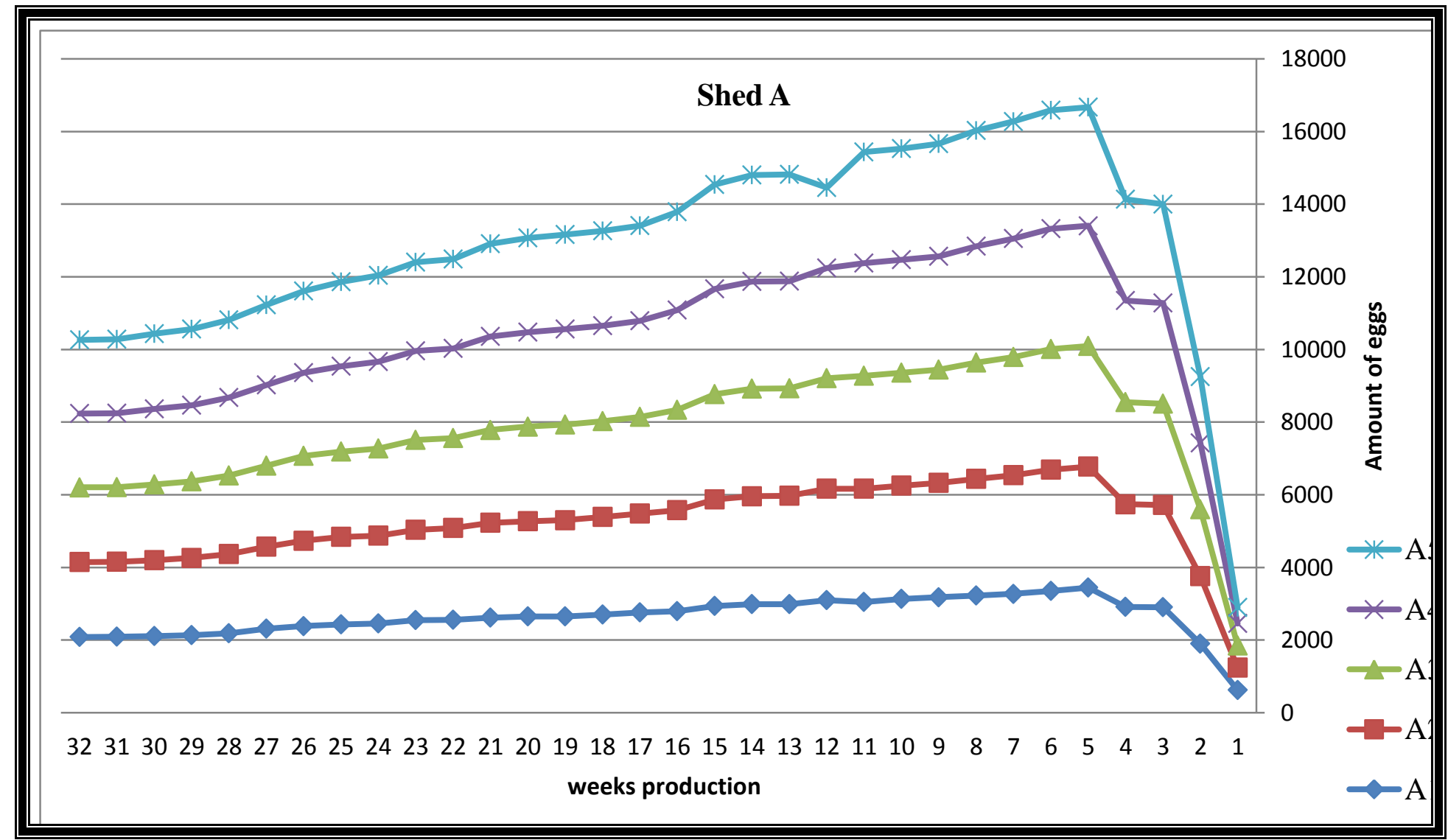

Fig (2): Comparing between the average weekly eggs production in different sectors in shed A at different temperature. 


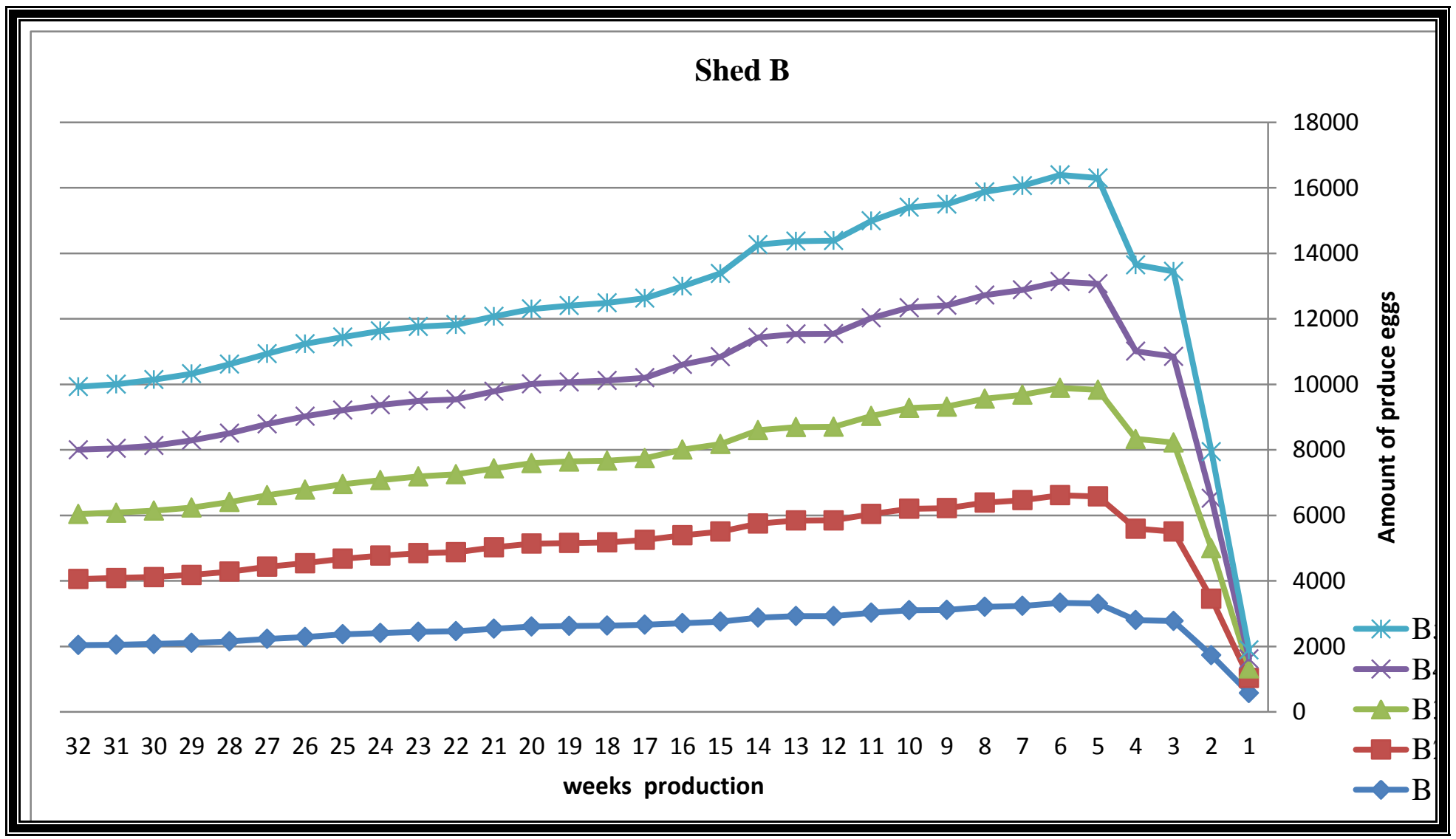

Fig (3): Comparing between the average weekly eggs production in different sectors in shed B at different temperature. 


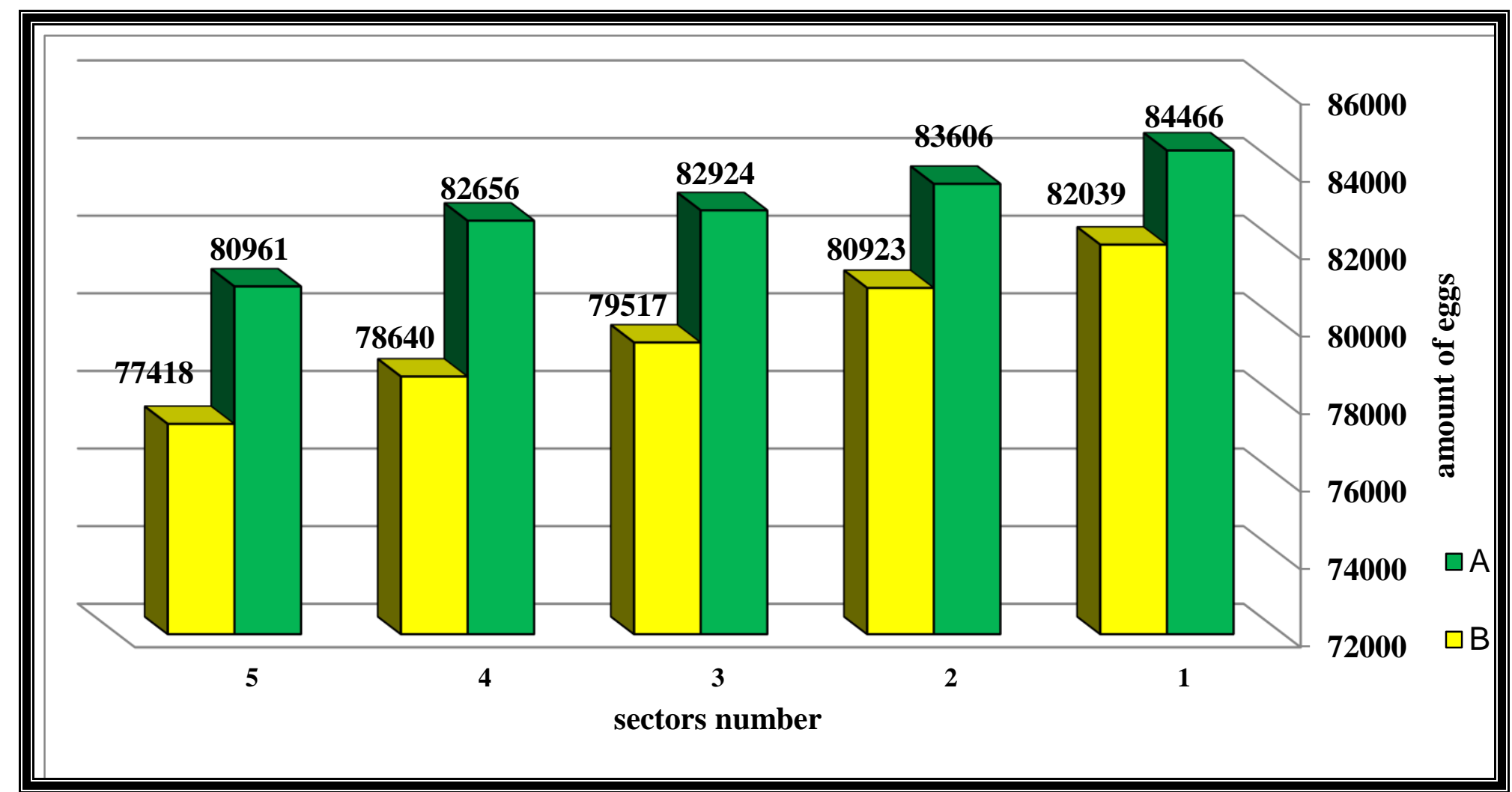

Fig (4): Comparing between the average weekly eggs produce in five sectors in the two sheds ( $A$ and $B$ ) at the poultry farm. 


\section{T-Test ANALYSIS}

PAIRS: A WITH B (PAIRED)

\begin{tabular}{|c|c|c|c|c|c|}
\hline \multicolumn{6}{|c|}{ Paired Samples Statistics } \\
\hline & & Mean & $\mathrm{N}$ & $\begin{array}{c}\text { Std. } \\
\text { Deviation }\end{array}$ & $\begin{array}{c}\text { Std. Error } \\
\text { Mean }\end{array}$ \\
\hline \multirow{2}{*}{ Pair 1} & A & $8.2923 \mathrm{E} 4$ & 5 & 1300.77585 & 581.72464 \\
\hline & $\mathrm{B}$ & 7.9707E4 & 5 & 1825.58136 & 816.42480 \\
\hline
\end{tabular}

Paired Samples Correlations

\begin{tabular}{|l|c|c|c|}
\hline & N & Correlation & Sig. \\
\hline Pair 1 A \& B & 5 & .969 & .007 \\
\hline
\end{tabular}

\section{Paired Samples Test}

\begin{tabular}{|c|c|c|c|c|c|c|c|c|}
\hline & \multicolumn{5}{|c|}{ Paired Differences } & \multirow{3}{*}{$\mathrm{t}$} & \multirow{3}{*}{$\mathrm{df}$} & \multirow{3}{*}{ Sig. (2-tailed) } \\
\hline & \multirow[t]{2}{*}{ Mean } & \multirow{2}{*}{$\begin{array}{c}\text { Std. } \\
\text { Deviation }\end{array}$} & \multirow{2}{*}{$\begin{array}{l}\text { Std. Error } \\
\text { Mean }\end{array}$} & \multicolumn{2}{|c|}{$\begin{array}{l}\text { 95\% Confidence Interval of the } \\
\text { Difference }\end{array}$} & & & \\
\hline & & & & Lower & Upper & & & \\
\hline Pair 1 A - B & $3.21520 \mathrm{E} 3$ & 650.00323 & 290.69028 & 2408.11439 & 4022.28561 & 11.061 & 4 & .000 \\
\hline
\end{tabular}




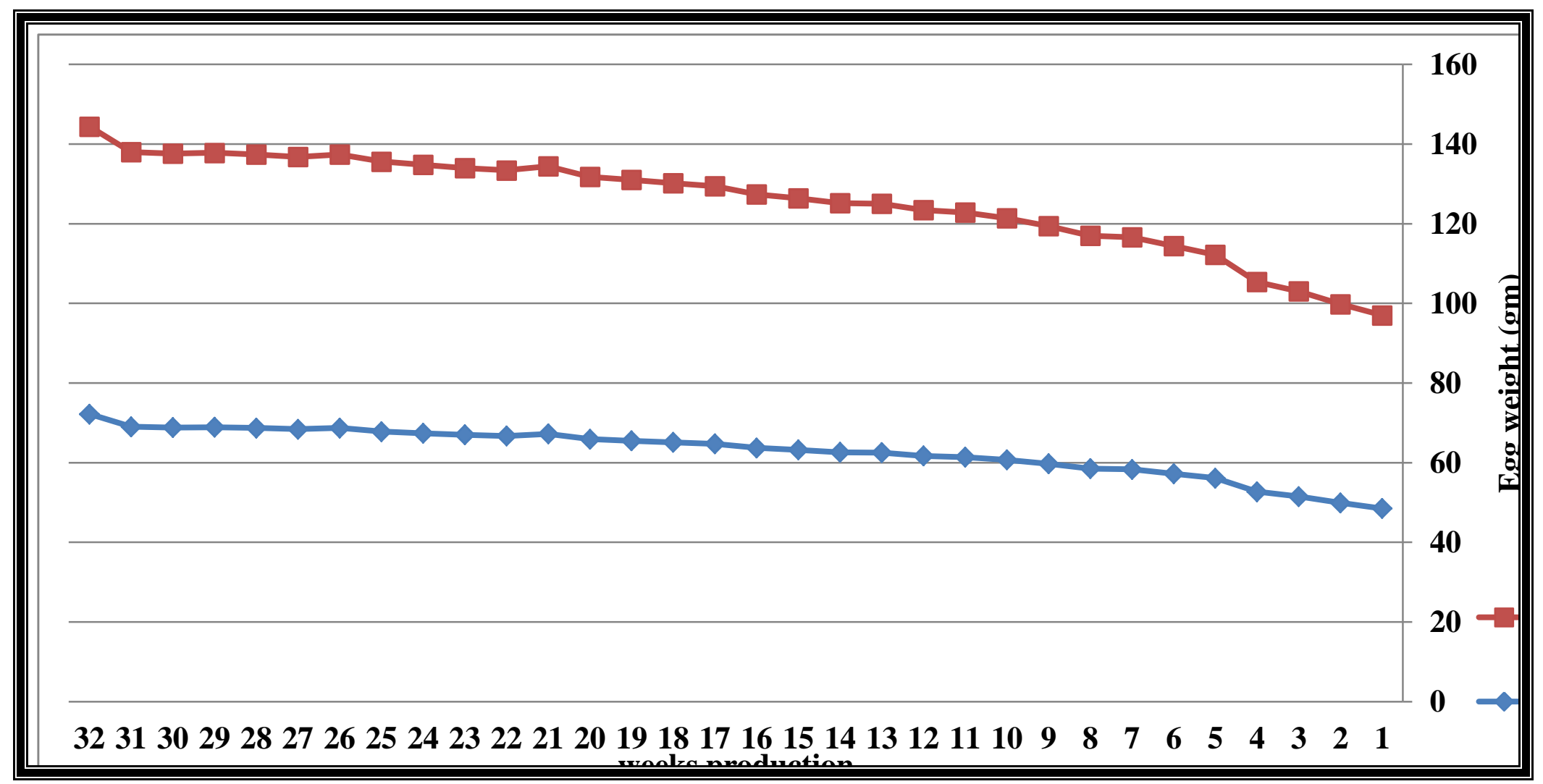

Fig. (5): Average weekly eggs weight values for of broiler breeders in the two sheds (A and B) at the poultry farm. 


\section{2-Costs of buying bulbs and maintenance:-}

Incandescent light bulbs in shed A:-

Price of lamps $=72 \times 4 / 7=41$ L.E

\section{Costs of maintenance :-}

Price of spoliage incandescent light bulbs $=72 \times 32 \times 4 / 7=1317$ L.E

Compact fluorescent light (CFL) lamps in shed B:-

Price of lamps $=72 \times 35 / 7=360$ L.E

It noticed there are no maintenance lamps in poultry compartment because of the long life span of the bulbs and up to 8000 hours.

3-The total cost to produce one egg:-

Total costs in shed A sectors

Total costs $=5.530+41+1.317=6.888$ L.E

Total costs in shed B sectors

Total costs $=1.438+360=1.798$ L.E

Tabel (2): Comparing between the cost of electricity for lamps to produce one egg in sheds (Aand B) different sectors.

\begin{tabular}{|c|c|c|c|c|c|c|}
\hline \multirow{2}{*}{ Sheds } & \multicolumn{3}{|c|}{ A } & \multicolumn{3}{|c|}{ B } \\
\hline & $\begin{array}{c}\text { Total } \\
\text { cost } \\
\text { (L.E) }\end{array}$ & $\begin{array}{l}\text { A.W.P.E.S } \\
\text { (Egg) }\end{array}$ & $\begin{array}{c}\text { P.C.E } \\
\text { (piaster) }\end{array}$ & $\begin{array}{c}\text { Total } \\
\text { cost } \\
\text { (L.E) }\end{array}$ & $\begin{array}{c}\text { A.W.P.E.S } \\
\text { (Egg) }\end{array}$ & $\begin{array}{c}\text { P.C.E } \\
\text { (piaster) }\end{array}$ \\
\hline 1 & 6.888 & 84.466 & 8.155 & 1.798 & 82.039 & 2.192 \\
\hline 2 & 6.888 & 83.606 & 8.239 & 1.798 & 80.923 & 2.222 \\
\hline 3 & 6.888 & 82.924 & 8.306 & 1.798 & 79.517 & 2.261 \\
\hline 4 & 6.888 & 82.656 & 8.333 & 1.798 & 78.640 & 2.286 \\
\hline 5 & 6.888 & 80.961 & 8.508 & 1.798 & 77.418 & 2.322 \\
\hline
\end{tabular}


Table (2) cleared that the cost of electricity required to produce one egg in shed B which used CFL lamps is lower cost by about $80 \%$ than the shed A which used incandescent light bulbs even if excess production returning were discount from electricity costs. It noticed also the increase of heat temerature rase the cost of electricity. The electrical energy cost to produce one egg in sectors A ranged from 8.155 to 8.508 piaster while it ranged from 2.192 to 2.322 piaster. The installation costs for CFL bulbs are considerably higher than incandescent bulbs but the price of maintenance spoliage incandescent bulbs exceed the cost while the CFL bulbs have long lifespan without maintenance.CFL bulbs representing a savings of the energy for the same sector lighting by use incandescent so it gained acceptance in recent years in the poultry industry.

\section{CONCLUSION}

1- The average weekly amount of eggs production in shed $\mathrm{A}$ at sectors $\mathrm{A}_{1}$, $\mathrm{A}_{2}, \mathrm{~A}_{3}, \mathrm{~A}_{4}$ and $\mathrm{A}_{5}$ were 84466, 83606, 82924, 82656 and 80961 eggs at temperature $20,21,22,23$ and $24{ }^{\circ} \mathrm{C}$ respectively while the percentage of the average weekly amount of eggs production decrease with a percentage of $1 \%, 1.83 \%, 2.14 \%$ and $4.15 \%$ in sectors $\mathrm{A}_{2}, \mathrm{~A}_{3}, \mathrm{~A}_{4}$ and $\mathrm{A}_{5}$ comparing to sector $\mathrm{A}_{1}$ by exceed heat temperature respectively.

2- The average weekly amount of eggs production in shed $B$ at sectors $B_{1}, B_{2}$, $\mathrm{B}_{3}, \mathrm{~B}_{4}$ and $\mathrm{B}_{5}$ were $82036,80923,79519,78640$ and 77418 eggs at temperature $20,21,22,23$ and $24{ }^{\circ} \mathrm{C}$ respectively while the percentage of the average weekly amount of eggs production decrease with a percentage of $1.36 \%$, $3.07 \%, 4.14 \%$ and $5.63 \%$ in sectors $\mathrm{B}_{2}, \mathrm{~B}_{3}, \mathrm{~B}_{4}$ and $\mathrm{B}_{5}$ comparing to sector $\mathrm{B}_{1}$ by exceed heat temperature respectively.

3- The results cleared that the percentage of average weekly quantity of produce eggs in the shed A for sectores A1, A2, A3, A4 and A5 which using incandescent light bulbs higher than the shed B for sectores B1, B2, B3, B4 and B5 using the CFL lamps by about $2.87 \%, 3.21 \%, 4.11 \%, 4.86 \%$ and $4.38 \%$ respectively.

4- The average weekly egg weight in sector A ranged from 48.5 to 72.2 gm while it ranged from 49.7 to 77.8 gm sector B respectively.

5- The electrical energy cost to produce one egg in sectors A1, A2, A3, A4 and A5 were 8.155, 8.239, 8.306, 8.333 and 8.508 piaster while it 
were 2.192, 2.222, 2.261, 2.286 and 2.286 piaster in sectors B1, B2, B3, B4 and B5 respectively.

From the obained data higher productivity of eggs occure by used incandescent bulbes as asource of light in comparing with the use of CFL lampes at a temperature $20{ }^{\circ} \mathrm{C}$ under the condition of experment.

\section{REFERENCES}

Borrile R., Garcia R.G., Royer A.F.B., Santana M.R., Colet S., Naas I.A., Caldara F.R., Almeida P. I., Rosa E.S. and Castilho V. (2013). The use of light-emitting diodes (LED) in commercial layer production. Rev. Bras. Cienc. Avic. vol. 15(2):135-140.

Commercial, industrial (2014) http: // blog.flexfireleds.com/the-benefitspoultry-led-lighting. Posted on Aug. 28, 2014.

Cobb-vantress (2015) www.cobb-vantress.com /.../advancements-inlighting-technology. Posted on April 2015.

Estrada-Pareja M.M, Marquez-Giron S.M and Restrepo L.F (2007). Effect of temperature and relative humidity on productive parameters and heat transfer in broiler chickens. Rev Col Cienc Pec; 20:288-303.

Gerry B. (2007). Lighting of poultry.J.of Primefact APRIL 2007 ThirdI eidtion ISSN 1832-6668. https://www.dpi.nsw.gov.au/animals-andlivestock/poultry-and-birds/poultry-planning-and-keeping/poultrykeeping-environment/lighting-of-poultry.

Huber-Eicher B., Suter A. and Spring-Stahli P. (2013): Effects of colored light-emitting diode illumination on behavior and performance of laying hens. Poultry. Sci. 92, 869-873.

Javid I., Sohail H.K., Nasir M., Tanver A. and Riaz A.P.(2014). Effects of egg size (weight) and age on hatching performance and chick quality of broiler breeder. Journal of Applied Animal Research Volume 44, - Issue 1, Pages 54-64.

Jacob J.P., H.R., Wilson R.D. Miles, Butcher G.D. and Mather F.B.(2015) Raising Chickens for Egg Production 
articles.extension.org/pages/.../ raising-chickens-for-egg-production http://www.printfriendly.com/.

Kamanli S., Durmus I., Demir S., and Tarim B. (2015) Effect of different light sources on performance and egg quality traits in laying hens. Europ.Poult.Sci. 79. August 2015, ISSN 1612-9199.

Keefe, T. J. (2010). "The Nature of Light". Community College of Rhode Island. Archived from the original on 12 June, 2010. Retrieved 18 September 2010.

Kwanchai A.G. and Arturo A.G. (1984) Statistical Procedures for Agricultural Research. Book.AWiley-Interscience Publication John Wiley \& Sons . New York. Second edation . Appandex.distribuation of (t) probabllity.pp 632.

Libbie J.(2015) Factors that Affect Egg Production in Chickens. article http://nwdistrict.ifas.ufl.edu/phag/2015/02/27/factors-that-affectegg-production-in-chickens/

Mendes A.S., Paixão S.J., Restelatto R., Morello G.M., Moura D.J.and Possenti J.C. (2013). Performance and preference of broiler chickens exposed to different lighting sources. Rev. Bras. Cienc. Avic. vol. 22:62-70.

Molino A.B., Garcia E.A., Santos G.C., Vieira Filho J.A., Baldo G.A.A.and Almeida P. I. (2015). Photo stimulation of Japanese quail. Poultry. Sci. 94(2):156-161.

Neil B. (2009) Energy Efficiency in Poultry House Lighting. N Burrow Service Concepts. Indianapolis, 2009 - ca.uky.edu.pp:1-29 http://www2.ca.uky.edu/poultryprofitability/Funding/Energy_Effici ency_in_Poultry_House_Lighting.pdf

Siopes, T.D. (1984) The effect of full spectrum fluorescent lighting on reproductive traits of caged turkey hens. Poultry Sci. May; 63(5): Pages 920-926. 
St-Pierre N.R, Cobanov B and Schnitkey G.X(2003). Economic Losses from Heat Stress by US Livestock Industries. J Dairy Sci ; 86(E) : E52E77.

Talukder.S, Islam.T, Sarker.S and Islam.M.M.(2010). Effects of environment on layer performance. J. Bangladesh Agril. Univ. 8(2): 253-258, 2010 ISSN 1810-3030.

Tamil Nadu Agricultural University (2018) Lighting in Poultry Production. http://agritech.tnau.ac.in/expert_system/poultry/Lighting \%20in\%20Poultry\%20Production.html\#

Wikipedia (2017) https://en.wikipedia.org/wiki/Compact-fluorescentlamp. 3 December 2017.

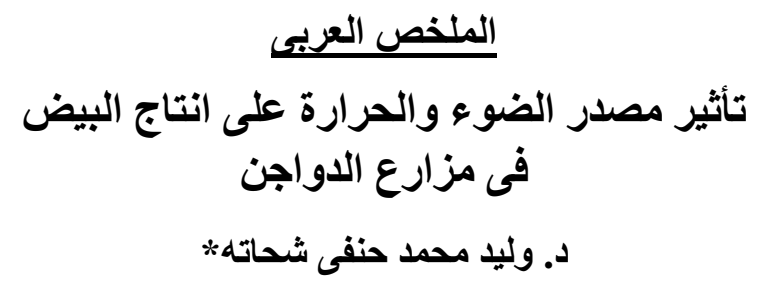

استهدف هذا البحث تقدير ومقارنة منوسط كمية البيض المنتج اسبو عيا فى عنابر مغلقة لتربيـة

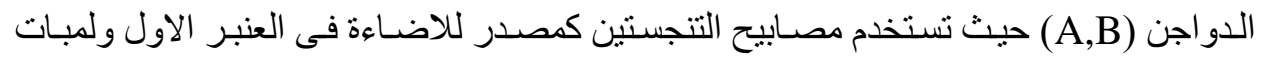

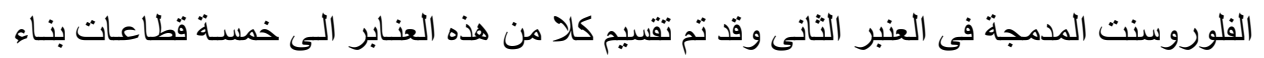

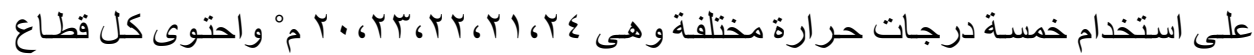

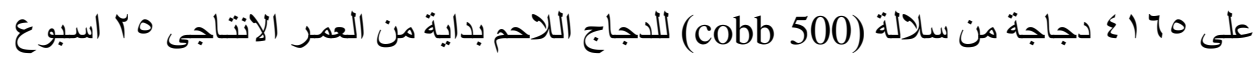

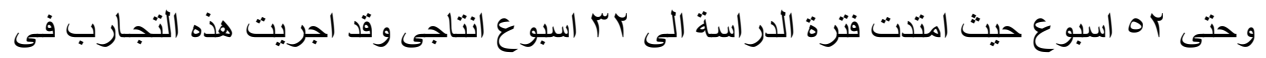

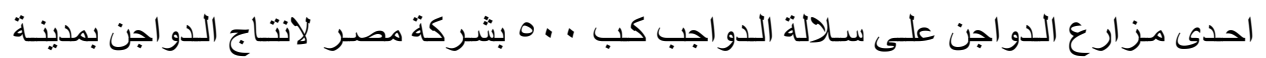

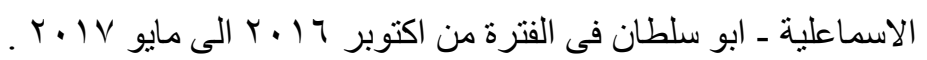

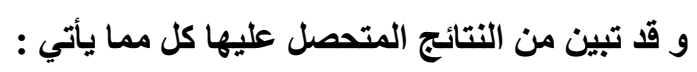

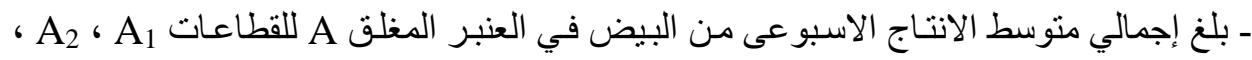

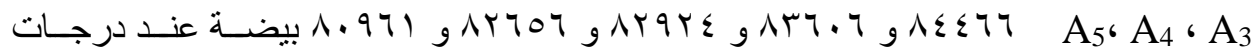

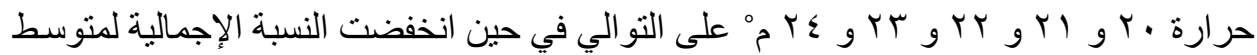

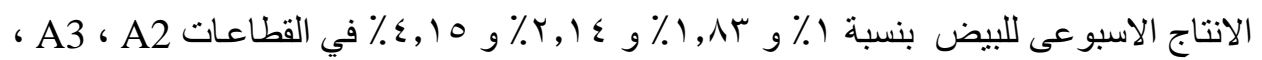
مقارنة بالقطاع A1 A4 وذللك بزيادة درجة الحر ارة على الترتيب. مدرس قسم الهندة الزراعية ـ كلية الزراعة والموارد الطبيعية - جامعة اسوان 


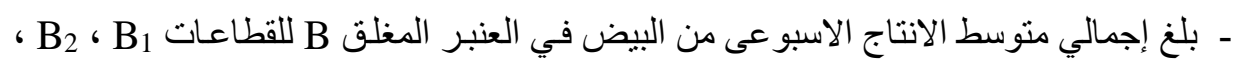

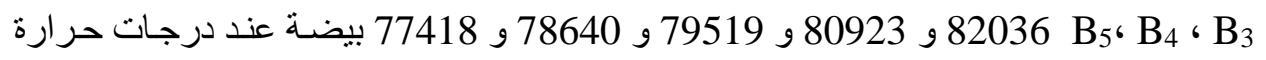

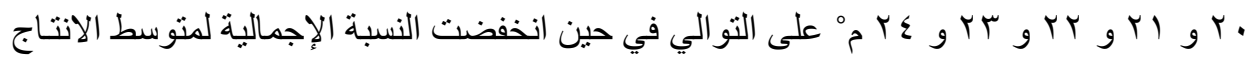

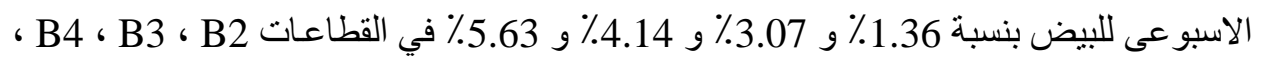
B5 مقارنة بالقطاع B1 وذللك بزيادة درجة الحر ارة على التئ الترتيب.

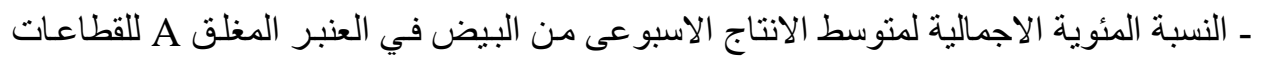

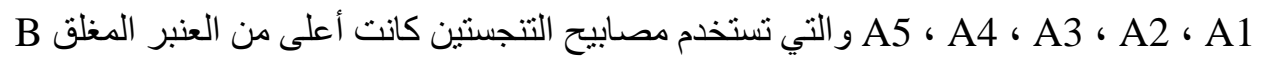

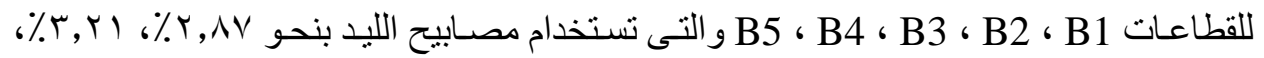

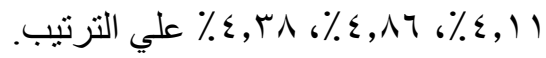

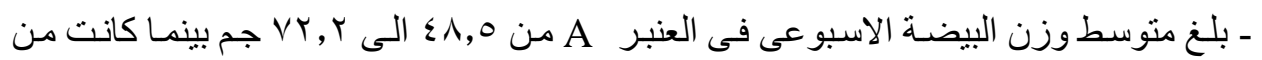

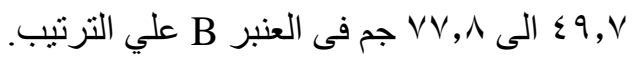

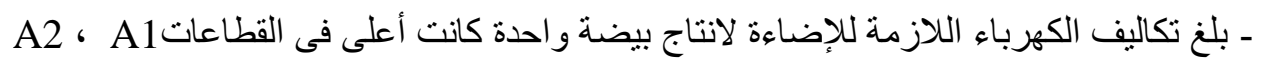

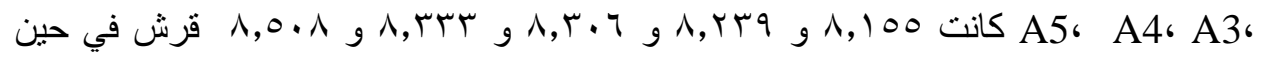
انخفضت فى القطاعات

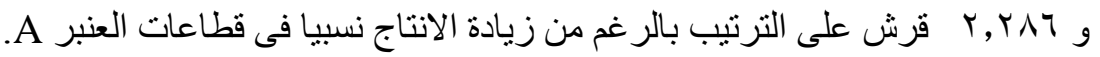

